\title{
Penerapan Teknik Clustering Dalam Mengembangkan Kemampuan Menulis Karangan Deskripsi Siswa Kelas IV MI Pesanten Datuk Sulaiman Palopo
}

\author{
Mirnawati $^{1^{*}}$, Firman $^{2}$ \\ 1,2 Institut Agama Islam Negeri (IAIN) Palopo \\ ${ }^{1^{*}}$ mirnawati@iainpalopo.ac.id $\quad{ }^{2}$ firman_999@iainpalopo.ac.id
}

\section{Abstrak}

Penelitian ini digolongkan ke dalam penelitian tindakan kelas. Penelitian tindakan kelas ini dilakukan untuk menggambarkan dan mengamati proses belajar siswa melalui penerapan teknik clustering dalam mengembangkan kemampuan menulis karangan deskripsi siswa kelas IV MI Pesanten Datuk Sulaiman Palopo. Mekanisme pelaksanaannya dengan dua siklus. Setiap siklus masing-masing dilaksanakan dengan tiga tahap, yaitu tahap (1) perencanaan, (2) tindakan dan pelaksanaan, (3) refleksi. Penelitian tindakan kelas ini merupakan salah satu upaya memperbaiki praktik pembelajaran bahasa Indonesia agar lebih bermanfaat. Dengan demikian, guru dapat mengetahui secara jelas masalah-masalah yang ada di kelas dan cara mengatasi masalah tersebut. Subjek penelitian ini adalah siswa kelas IV MI Pesanten Datuk Sulaiman Palopo tahun pelajaran 2017/2018 dengan jumlah murid 30 orang. Teknik yang digunakan untuk mengumpulkan data dalam penelitian ini adalah observasi, dokumentasi, dan penugasan. Hasil penelitian menunjukkan bahwa penerapan teknik clustering dapat meningkatkan pembelajaran menulis karangan deskripsi siswa kelas IV MI Pesanten Datuk Sulaiman Palopo. Peningkatan yang dimaksud, yaitu peningkatan proses dan hasil belajar menulis karangan deskripsi siswa. Peningkatan tersebut tampak pada proses pembelajaran siklus I dan siklus II.

Kata Kunci: Teknik Clustering, Karangan Deskripsi

\section{Pendahuluan}

Keterampilan menulis merupakan salah satu aspek keterampilan berbahasa yang sangat dibutuhkan, terutama dalam mengungkapkan ide, pikiran, dan perasaan melalui karangan, baik fiksi maupun nonfiksi. Bahkan, kehidupan manusia hampir tidak dapat dipisahkan dari kegiatan menulis. Oleh karena itu, keterampilan menulis harus diajarkan dengan baik kepada siswa. Para siswa di sekolah harus dibina, dibekali, dan ditempa keterampilan menulisnya sehingga mereka mampu menuangkan ide, pikiran, perasaan, dan gagasan dalam berbagai jenis.

Dalam pengajaran mengarang, cerita tentang gambar berseri telah memakai judul dan penggunaan kalimatnya lebih banyak. Pada saat menceritakan benda, hewan, atau tanaman yang sesuai di lingkungan, anak telah menjelaskan benda itu. Misalnya, anak menjelaskan tentang ayam. Anak menjelaskan tentang tubuh ayam, makanannya, cara hidupnya, cara memeliharanya, guna ayam bagi manusia, perbedaan ayam dengan unggas lainnya, dan seterusnya. Anak dibiasakan mengamati lingkungan sekitar (pasar, toko, kantor pos, bank, tempat pertunjukan, dan sebagainya) secara lebih rinci sehingga siswa dapat menuliskan berpuluh-puluh kalimat tentang sesuatu. Demikian juga dalam hal menilai isi (Purwanto dan Alim, 1997: 62). 
Dalam pengajaran mengarang kreatif ini, siswa dibiasakan menentukan pokok pikiran dari karangannya. Pada saat menceritakan gambar berseri, siswa dituntun lebih rinci menjelaskan setiap gambar. Pengamatan tentang gambar lebih rinci. Dengan demikian, penjelasan mereka tentang gambar lebih rinci dan jelas. Jadi, terjadi pengembangan orisinalitasnya. Lambat laun, secara bertahap siswa sebaiknya tidak lagi menggunakan media gambar. Mereka dilatih dapat mengembangkan karangan berdasarkan pengalaman dan imajinasi mereka. Tentu saja hal itu harus melalui latihan-latihan secara bertahap. Mulai dari menentukan judul, latihan melengkapi paragraf yang hilang, dilanjutkan dengan menyelesaikan karangan (Purwanto dan Alim, 1997: 62-63).

Pengajaran keterampilan menulis tampaknya belum menggembirakan. Salah satu realita konkret yang mendukung pernyataan tersebut adalah kondisi pengajaran keterampilan menulis di kelas IV MI Pesanten Datuk Sulaiman Palopo. Berdasarkan pengalaman terhadap keadaan pembelajaran menulis di sekolah ini, diperoleh gambaran bahwa motivasi dan kemampuan menulis siswa masih sangat rendah, siswa sering merasa jenuh jika disuruh mengarang, tidak ada siswa yang menonjol dalam pembelajaran mengarang, dan hasil karangan siswa, termasuk di kelas-kelas tinggi masih sangat memprihatinkan. Rendahnya kemampuan menulis disebabkan oleh beberapa faktor, antara lain: (1) pokok bahasan menulis tidak memperoleh perhatian serius dari guru dan motivasi siswa dalam menulis sangat minim dan (2) sarana dan metode atau strategi pembelajaran menulis belum efektif. Hal tersebut mengisyaratkan bahwa dibutuhkan pembenahan dalam pembelajaran menulis.

Jenis karangan yang dapat diajarkan dengan mudah pada peserta didik tingkat sekolah dasar adalah karangan deskripsi. Karangan deskripsi adalah karangan menggambarkan sesuatu dengan jelas dan terperinci. Karangan deskrispi bertujuan melukiskan atau memberikan gambaran terhadap sesuatu dengan sejelas-jelasnya sehingga pembaca seolaholah dapat melihat, mendengar, membaca, atau merasakan hal yang dideskripsikan. (Nurdjan, Firman, \& Mirnawati, 2018:66).

Setiap guru bahasa harus dapat membantu dan membimbing para pelajar untuk dapat mengembangkan dan meningkatkan keterampilan-keterampilan yang mereka butuhkan dalam menulis (Tarigan, 1986: 14). Seorang guru yang profesional harus mampu menulis dan menerapkan metode, strategi, dan media pembelajaran yang tepat untuk meningkatkan keterampilan siswa, khususnya keterampilan menulis.

Menulis merupakan suatu proses sekaligus suatu produk (hasil). Menulis sebagai suatu proses berupa pengelolaan ide atau gagasan dari tema atau topik yang dipilih untuk dikomunikasikan. Salah satu cara atau metode yang digunakan untuk memunculkan ide adalah metode quantum writing.

Quantum writing merupakan cara cepat dan bermanfaat untuk merangsang munculnya potensi menulis. Dalam quantum writing diperkenalkan beberapa teknik dalam menulis. Hernowo (2003: 140) mengklasifikasikan teknik menulis menjadi beberapa teknik, yaitu: (1) menulis dengan menggunakan peta pikiran; (2) menulis dengan menggunakan iringan musik; (3) menulis dengan gaya clustering (pengelompokan).

\section{Keterampilan Menulis}

Kemampuan menulis adalah keterampilan seseorang menggunakan bahasa tulis sebagai alat, baik wadah maupun media untuk memaparkan isi jiwanya, penghayatan, dan pengalamannya secara teratur. 
Indikator keterampilan menulis ini, yaitu: 1) kemampuan memilih ide yang akan dipaparkan; 2) kemampuan menata atau mengorganisasikan ide pilihannya secara sistematis; 3) kemampuan menggunakan bahasa menurut kaidah-kaidah serta kebiasaan pemakaian bahasa yang telah umum sifatnya; 4) kemampuan menggunakan gaya bahasa, yaitu pilihan struktur dan kosakata untuk memberikan nada atau makna terhadap karangan itu; 5) kemampuan mengatur mekanisme tulisan, yaitu tata cara penulisan lambang-lambang bahasa tertulis (ejaan) yang dipaparkan dalam bahasa tersebut (Halim, 2004: 23).

Ada beberapa alasan yang menyebabkan kemampuan menulis itu menjadi penting, yaitu:

1) Kegiatan menulis adalah suatu sarana untuk menemukan sesuatu. Dalam hal ini, dengan menulis kita dapat merangsang pemikiran kita dan kalau itu dilakukan dengan intensif, maka akan dapat membuka penyumbat otak kita dalam rangka mengangkat ide dan informasi yang ada di alam bawah sadar pemikiran kita.

2) Kegiatan menulis dapat memunculkan ide baru. Ini terutama terjadi kalau kita membuat hubungan antara ide yang satu dengan yang lain dan melihat keterkaitannya secara keseluruhan.

3) Kegiatan menulis dapat melatih kemampuan mengorganisasi dan menjernihkan berbagai konsep atau ide yang kita miliki. Dengan menuliskan berbagai ide itu berarti kita harus dapat mengaturnya di dalam suatu bentuk tulisan yang padu.

4) Kegiatan menulis dapat melatih sikap objektif yang ada pada diri seseorang. Dengan menuliskan ide-ide itu ke dalam suatu tulisan berarti akan melatih diri kita untuk membiasakan membuat jarak tertentu terhadap ide yang kita hadapi dan mengevaluasinya.

5) Kegiatan menulis dapat membantu diri kita untuk menyerap dan memproses informasi. Bila kita akan menulis sebuah topik, maka hal itu berarti kita harus belajar tentang topik itu dengan lebih baik. Apabila kegiatan seperti itu kita lakukan terus-menerus, maka berarti akan dapat mempertajam kemampuan kita dalam menyerap dan memproses informasi.

6) Kegiatan menulis akan memungkinkan kita untuk berlatih memecahkan beberapa masalah sekaligus. Dengan menempatkan unsur-unsur masalah dalam sebuah tulisan berarti kita akan dapat menguji dan, kalau perlu, memanipulasinya.

7) Kegiatan menulis dalam sebuah bidang ilmu memungkinkan kita untuk menjadi aktif dan tidak hanya menjadi penerima informasi.

\section{Clustering (Pengelompokan)}

Clustering (pengelompokan) yang dikembangkan Gabrielle Rico (1999: 180) adalah suatu cara memilih gagasan dan menuangkannya ke atas kertas secepatnya tanpa mempertimbangkan kebenaran atau nilainya. Pengelompokan yang dilakukan dengan cara menuliskan kata-kata di atas kertas menjadi proses berpikir yang terjadi di dalam otak. Penggunaan teknik pengelompokan untuk merangsang gagasan dalam proyek penulisan akan membantu memberikan titik awal rencana yang akan ditulis (Hernowo, 2003: 182).

Menurut Caryn Meriam (2005: 349), clustering (pengelompokan) adalah teknik yang membantu mengembangkan tulisan dengan berbagai cara sekaligus dengan mengambil suatu gagasan dan membuat percabangan ke berbagai arah.

Teknik clustering sangat ampuh untuk merangsang kemampuan menulis karena membuat penulis secara alamiah dan mengabaikan penyuntingan untuk sementara waktu. Dalam pengelompokan, penulis menempatkan setiap kata setingkat dengan gagasan yang lainnya. 
Ketika penulis membuat pengelompokan, penulis membiarkan otak bekerja untuk terus melahirkan gagasan. Namun, setelah selesai melakukan pengelompokan, penulis tidak perlu mengambil semua gagasan yang dihasilkan. Penulis dapat mengembangkan gagasan sesuai dengan yang diinginkan.

Melalui clustering akan muncul sejumlah alternatif dari bagian pikiran kita dan dalam alternatif tersebut pengalaman hidup melebur menjadi satu. Teknik ini merupakan alat menulis yang bisa menerima rasa penasaran, ketidaktahuan, serta sesuatu yang tampak kacau-balau yang secara bertahap bisa memetakan pemandangan batin seiring dengan timbulnya gagasan.

Pemanfaatan teknik clustering (pengelompokan) dalam merancang karangan memiliki beberapa keuntungan, yakni:

a. memudahkan untuk membuat dan melihat hubungan-hubungan antara gagasan;

b. membantu menelusuri jalur yang dilalui otak untuk sampai pada suatu konsep tertentu.

c. membantu mengembangkan gagasan-gagasan yang telah dikemukakan.

\section{Metode Penelitian}

Penelitian ini digolongkan ke dalam penelitian tindakan kelas. Penelitian tindakan kelas ini dilakukan untuk menggambarkan dan mengamati proses belajar siswa melalui penerapan teknik clustering dalam mengembangkan kemampuan menulis karangan deskripsi siswa kelas IV MI Pesanten Datuk Sulaiman Palopo. Mekanisme pelaksanaannya dengan dua siklus. Setiap siklus masing-masing dilaksanakan dengan tiga tahap, yaitu tahap (1) perencanaan, (2) tindakan dan pelaksanaan, (3) refleksi. Penelitian tindakan kelas ini merupakan salah satu upaya memperbaiki praktik pembelajaran bahasa Indonesia agar lebih bermanfaat. Dengan demikian, guru dapat mengetahui secara jelas masalah-masalah yang ada di kelas dan cara mengatasi masalah tersebut.

Subjek penelitian ini adalah siswa kelas IV MI Pesanten Datuk Sulaiman Palopo tahun pelajaran 2017/2018 dengan jumlah murid 30 orang. Teknik yang digunakan untuk mengumpulkan data dalam penelitian ini adalah observasi, dokumentasi, dan penugasan.

Pelaksanaan pembelajaran menulis dengan teknik clustering dilakukan dalam dua kali pertemuan untuk setiap siklus. Dalam setiap pertemuan, siswa akan diberikan materi menulis berdasarkan Kurikulum Tingkat Satuan Pendidikan. Dalam pembelajaran tersebut, siswa dikelompokkan atas beberapa kelompok.

\section{Hasil Penelitian}

\section{Paparan Data Siklus I}

Pelaksanaan pembelajaran mengarang dengan penerapan teknik clustering dalam mengembangkan kemampuan menulis karangan deskripsi siswa kelas IV MI Pesanten Datuk Sulaiman Palopo dirancang oleh peneliti dengan guru kelas secara kolaboratif. Peneliti bersama guru melakukan diskusi mengenai rancangan tindakan yang terkait dengan penelitian tindakan kelas ini, yang meliputi: bahan yang akan diajarkan, waktu, sumber belajar, media pembelajaran, dan penilaian akhir dalam membelajarkan siswa sehingga tujuan pembelajaran dapat tercapai secara maksimal.

Sebelum merancang rencana tindakan dalam pembelajaran mengarang dengan teknik clustering, dilakukan identifikasi awal tentang kesulitan, pengalaman, perasaan, dan hambatan yang dialami siswa dalam proses mengarang. Identifikasi yang dilakukan secara kolaboratif antara peneliti dan guru meliputi lima hal berikut ini. 
1) Mengidentifikasi kesulitan yang terkait dengan proses menulis, khususnya mengarang.

2) Mengidentifikasi pengalaman yang dialami siswa selama pembelajaran menulis berlangsung, khususnya mengarang.

3) Mengidentifikasi perasaan yang sering muncul ketika pembelajaran menulis sedang berlangsung atau ketika siswa diminta mengarang.

4) Mengidentifikasi hambatan yang dialami oleh siswa pada saat pembelajaran mengarang beserta tingkat kerumitannya.

5) Mengidentifikasi tindak lanjut yang diinginkan oleh siswa yang berkaitan dengan pembelajaran mengarang. Hal ini dimaksudkan untuk memperoleh gambaran bahwa seorang guru yang baik akan memperhatikan hal yang diinginkan siswa demi kelancaran proses belajar mengajarnya tanpa mengabaikan etika pendidikan yang berlaku.

Pelaksanaan kegiatan pembelajaran pada siklus I direncanakan sebagai berikut.

1) Peneliti bertindak sebagai pengamat dan pengarah pelaksanaan pembelajaran mengarang yang dilakukan oleh guru dengan teknik clustering. Guru melaksanakan pembelajaran menulis dengan teknik clustering kepada siswa sesuai dengan rencana pembelajaran yang telah disusun secara kolaboratif, sedangkan peneliti mengamati secara totalitas.

2) Kegiatan yang direncanakan dilakukan oleh guru dalam pelaksanaan pembelajaran untuk membangkitkan minat siswa, meliputi:

a) pemberian apersepsi;

b) memilih tema karangan berdasarkan pengalaman siswa;

c) menyiapkan media pembelajaran.

\section{Paparan Data Siklus II}

Perencanaan pembelajaran pada siklus II merupakan tindak lanjut yang dirancang untuk memperbaiki proses dan hasil pembelajaran pada siklus I. Bagian-bagian yang menyebabkan proses pembelajaran tergolong sangat kurang (SK), kurang (K), cukup (C) diupayakan untuk diperbaiki, sedangkan bagian yang termasuk baik (B) atau telah memenuhi target tetap dipertahankan. Pembelajaran pada siklus II direncanakan berupa peningkatan motivasi yang dilakukan guru kepada siswa dengan menugasi salah seorang siswa membaca puisi sebagai selingan dan hiburan sebelum pembelajaran inti berlangsung.

Berdasarkan hasil refleksi yang dilakukan pada siklus I, diketahui bahwa hambatan yang terbesar dialami siswa adalah suasana kelas yang kurang mendukung penerapan pembelajaran menulis dengan teknik clustering. Oleh karena itu, sangat perlu dilakukan pembenahan untuk menciptakan suasana kelas yang menyenangkan dan tidak membosankan. Selain itu, diperlukan penyusunan indikator untuk melatih siswa kreatif dalam mengarang dengan memanfaatkan teknik clustering.

Kegiatan pembelajaran dilaksanakan dalam dua kali pertemuan dengan frekuensi waktu $4 \mathrm{x}$ 45 menit. Kegiatan pembelajaran dilaksanakan sebagai tindak lanjut dari pembelajaran pada siklus I, yaitu: mengembangkan kemampuan siswa dalam mengarang dengan pemilihan tema berdasarkan pengalaman untuk menumbuhkan daya imajinasi siswa dengan memanfaatkan teknik clustering. 


\section{Pembahasan}

\section{Analisis Temuan Siklus I}

\section{Tindakan}

Pelaksanaan pembelajaran menulis karangan deskripsi dengan teknik clustering dilakukan secara kolaborasi antara guru dan peneliti. Guru dan peneliti membuat desain pembelajaran dan mendeskripsikan hal-hal yang dipelajari di kelas IV semester ganjil dan menyamakan persepsi tentang rencana pembelajaran yang diteliti. Setelah itu, peneliti memberi masukan yang berkaitan dengan sumber belajar, media pembelajaran, dan cara menerapkan teknik clustering.

Guru merancang rencana tindakan dalam pembelajaran mengarang dengan menerapkan teknik clustering dan melakukan identifikasi awal tentang kesulitan, pengalaman, perasaan, dan hambatan yang dialami siswa dalam proses mengarang.

Dalam kegiatan pendahuluan, guru membuka pelajaran dengan apersepsi dan membangkitkan motivasi belajar siswa untuk mengikuti pelajaran. Selanjutnya, guru mengemukakan tema dan tujuan pembelajaran, yakni mengarang dengan menerapkan teknik clustering. Siswa tampak tegang dan kurang memahami materi yang telah disampaikan oleh guru.

Dalam kegiatan inti, proses pembelajaran berlangsung sebagai berikut.

1) Guru mengajukan pertanyaan kepada siswa mengenai langkah-langkah mengarang.

2) Guru kemudian menginstruksikan kepada siswa untuk membentuk kelompok berdasarkan kesamaan pengalaman.

3) Guru menyuruh siswa secara berkelompok membuat curah gagasan dengan menggunakan teknik clustering berdasarkan hal-hal yang dirasakan.

4) Guru menyuruh setiap anggota kelompok untuk mengarang berdasarkan pengalamannya dengan mengembangkan curah gagasan yang telah dibuat secara berkelompok.

5) Setelah selesai mengarang, guru menyuruh salah seorang siswa dari setiap kelompok untuk membacakan karangannya di depan kelas, kelompok lain memberi tanggapan.

6) Guru menginstruksikan kepada siswa untuk mengumpulkan karangannya berdasarkan kelompoknya masing-masing.

7) Guru kembali menunjuk salah seorang siswa untuk ke depan dan menulis salah satu topik. Siswa tersebut menulis curah gagasan yang disebut oleh teman-temannya. Selanjutnya, seluruh siswa mengarang berdasarkan pengalaman dengan mengembangkan curah gagasan yang telah dibuat secara klasikal.

8) Guru kembali menyuruh siswa untuk membacakan hasil karangannya di depan kelas, siswa lain memberi tanggapan.

9) Setelah itu, hasil karangan siswa dikumpul kepada guru untuk diperiksa dan dinilai.

Kegiatan pembelajaran pada siklus I berlangsung selama dua kali pertemuan, yaitu 4 × 45 menit. Berdasarkan pembelajaran yang dilakukan pada pertemuan pertama, dapat diketahui bahwa guru berusaha membangkitkan semangat/motivasi dan minat siswa dengan mengajukan pertanyaan mengenai langkah-langkah mengarang. Ada beberapa siswa menanggapinya dan sebagian besar tidak memberi respons. 
Siswa tidak memberi respons bukan karena tidak tahu, melainkan merasa takut dan malu mengemukakan pendapatnya. Mereka takut jawaban yang diungkapkan salah dan mungkin sebagian siswa kurang mengerti tentang hal yang dipertanyakan oleh gurunya. Hal inilah yang menjadi laporan proses pembelajaran mengarang dengan menggunakan teknik clustering pada siklus I.

Pada saat kegiatan belajar mengajar berlangsung dan ketika guru memperkenalkan teknik clustering dalam mengarang, siswa bingung hendak memulai dari mana. Hal utama yang kurang mendukung keberhasilan pembelajaran ini adalah teknik clustering dalam mengarang merupakan hal yang baru bagi siswa sehingga pemanfaatannya dalam pembelajaran mengarang berdasarkan pengalaman belum maksimal.

Hal-hal yang terjadi dalam interaksi guru dan siswa serta antara siswa dan siswa dalam kegiatan belajar mengajar pada siklus I dapat disimpulkan oleh peneliti sebagai berikut.

1) Situasi kelas kurang mendukung karena ada beberapa siswa yang belum mengerti tentang cara penerapan teknik clustering dalam mengarang.

2) Guru tidak menyediakan hadiah bagi siswa yang karangannya memenuhi kriteria penilaian sehingga siswa tidak termotivasi dalam mengarang.

3) Guru kurang memahami cara menerapkan teknik clustering dalam mengarang.

\section{Pengamatan}

Pembelajaran pada siklus I dilaksanakan dalam dua kali pertemuan dan berlangsung selama $4 \times 45$ menit. Pembelajaran mengarang berdasarkan pengalaman dengan menggunakan teknik clustering baru pertama kali didapatkan/dialami siswa kelas IV MI Pesanten Datuk Sulaiman Palopo. Selama ini dalam mengarang, siswa kadangkala menggunakan kerangka karangan. Bahkan, tidak jarang mereka langsung mengungkapkan pikiran dan perasaannya dalam bentuk karangan.

Sewaktu guru memperkenalkan teknik clustering dalam mengarang, rata-rata siswa merasa bingung harus memulai dari mana. Terlebih lagi ketika guru menunjuk salah seorang siswa ke depan untuk mencurahkan gagasannya. Siswa tersebut terdiam dan tidak melakukan apa-apa. Namun, setelah guru menjelaskan ulang dan mengujicobakan pengajaran mengarang dengan teknik clusteing kembali kepada siswa, ternyata mereka mampu membuat curah gagasan walaupun kurang sempurna.

Ketika guru membagikan kertas kepada siswa dan meminta mereka membuat lingkaran besar di tengah-tengah kertas serta menulis topik yang dipilih, beberapa siswa berkeliaran bertanya kepada temannya yang dianggap memahami penjelasan yang disampaikan oleh guru.

Faktor penghambat yang berasal dari pihak guru adalah guru belum memahami betul tata cara pembelajaran menulis dengan model pembelajaran khususnya teknik clustering. Karena penjelasan guru tidak bisa dipahami siswa dengan baik, sejumlah siswa akhirnya berkeliaran di dalam kelas untuk menanyakan teknik clustering, baik kepada guru maupun kepada siswa lain yang dianggap telah paham. Hal ini membuat suasana kelas menjadi ribut. Selain itu, teknik tersebut masih asing bagi guru sehingga ia belum mampu mengarahkan siswa secara maksimal. Ada kesan bahwa siswa dalam mengarang berfokus pada kerangka karangan. Jadi, teknik clustering belum diterapkan secara maksimal. 


\section{Refleksi}

Dalam refleksi ini disimpulkan bahwa kegiatan pembelajaran belum optimal karena guru belum mampu memberikan pemahaman kepada siswa tentang tata cara pelaksanaan pembelajaran menulis dengan teknik clustering. Teknik ini belum diterapkan dengan baik karena guru kurang maksimal mengarahkan siswa secara bertahap dalam mengarang sehingga siswa kurang memberi respons. Selain itu, pembelajaran yang dilaksanakan pada jam pelajaran terakhir menyebabkan siswa merasa lapar, capek, dan mengantuk. Hal ini membuat siswa kurang mampu membuat karangan. Kondisi dan suasana kelas yang ribut akibat siswa belum memahami betul pelaksanaan menulis dengan teknik clustering menyebabkan kegiatan pembelajaran kurang optimal. Faktor lain yang menyebabkan pembelajaran kurang maksimal, yaitu: guru kurang memantau kegiatan siswa; siswa malas bertanya dan enggan untuk meminta diberi contoh.

Dalam pelaksanaan pembelajaran menulis dengan teknik clustering membuat siswa merasa senang. Dari sejumlah karangan yang dikumpulkan oleh guru, dapat disimpulkan bahwa hanya beberapa orang siswa yang mampu membuat karangan sesuai dengan target. Karangan siswa belum memenuhi aspek penilaian seperti curah gagasan yang dibuat kurang sesuai dengan isi karangan, jumlah kata, pemilihan kata, organisasi karangan, dan penggunaan PUEBI yang belum memadai. Jadi, karangan yang dibuat oleh siswa belum memenuhi syarat penilaian. Hal ini terbukti dengan adanya siswa yang enggan membaca karangannya karena merasa malu dan menyadari bahwa pekerjaannya masih perlu diperbaiki.

Berdasarkan hasil kegiatan refleksi ini, disusun rencana pembelajaran untuk meningkatkan kemampuan siswa dalam mengarang dengan penerapan teknik clustering. Siswa harus mampu membangkitkan keberanian dan kreativitas dalam mengemukakan pendapat dan gagasannya berdasarkan hal yang pernah mereka alami (pengalaman mereka) atau tentang peristiwa dan perasaannya terhadap suatu peristiwa. Selanjutnya, siswa menetukan tema yang akan dijadikan acuan dalam mengarang.

Situasi kelas yang dulunya ribut dirancang sedemikian rupa sehingga menimbulkan kesan yang lebih nyaman. Guru dianjurkan untuk memantau dan mengarahkan siswa apabila mengalami hambatan. Selain itu, untuk membangkitkan minat dan motivasi siswa dalam mengarang, perlu penyediaan hadiah sebagai penguatan.

Hal yang paling penting dibenahi adalah aktivitas belajar yang dapat meningkatkan motivasi siswa untuk membelajarkan dirinya, menciptakan kebiasaan menulis berdasarkan pengalaman yang dialaminya, dan menumbuhkan kemampuan berpikir kritis dalam mengarang sehingga pengetahuan itu bukan saja bermakna bagi siswa, melainkan juga menjadi sebuah informasi yang dimiliki siswa. Hasil refleksi siklus I menjadi dasar penyusunan siklus II.

\section{Temuan Analisis Siklus I}

Temuan penelitian yang diperoleh dari hasil analisis siklus I diuraikan sebagai berikut.

1) Guru memotivasi siswa dengan mengemukakan tema dan tujuan pembelajaran.

2) Pertanyaan tentang langkah-langkah mengarang yang diajukan oleh guru bertujuan untuk membangkitkan skemata siswa mengenai hal tersebut.

3) Cara guru mengarahkan siswa dalam mengarang dengan menerapkan teknik clustering belum maksimal. 
4) Siswa mengalami kesulitan mengembangkan curah gagasan yang dibuat karena minimnya perbendaharaan kata yang dikuasai.

5) Suasana kelas yang tidak menyenangkan (ribut) membuat siswa tidak berkonsentrasi dalam menulis dan sikap masa bodoh ditunjukkan oleh siswa dalam proses pembelajaran.

6) Guru kurang berperan aktif dalam membimbing dan memotivasi siswa dalam mengarang berdasarkan teknik clustering.

7) Pemahaman guru dan siswa belum memadai mengenai teknik clustering.

8) Penilaian guru terhadap hasil karangan siswa kurang mendapat respons yang baik, seperti tidak menyediakan hadiah bagi karangan yang terbaik.

Untuk mengukur keberhasilan pembelajaran dalam siklus I dilakukan evaluasi. Evaluasi (penilaian) dalam pembelajaran menulis ini dilakukan setelah siswa mengarang yang berfokus pada curah gagasan yang dibuat berdasarkan teknik clustering. Pada dasarnya, teknik clustering merupakan salah satu cara yang dapat digunakan untuk mencurahkan gagasan dengan membuat asosiasi-asosiasi kata yang selanjutnya digunakan sebagai acuan dalam mengarang. Jika karangan yang dibuat siswa sesuai dengan curah-gagasan, maka penilaian merujuk pada penulisan yang dilakukan secara objektif (aspek kognitif) dan beberapa aspek penilaian dalam mengarang. Namun, penilaian yang dilakukan lebih dominan dititikberatkan pada aspek psikomotorik dan afektif.

Setiap aspek penulisan yang dinilai mendapat skor tersendiri untuk mengetahui tingkat keberhasilan siswa dalam pembelajaran mengarang. Misalnya, untuk mengetahui apakah setelah hasil karangan siswa direfleksi dan diberi pembelajaran ulang sesuai dengan keinginan dan kebutuhan mereka, terdapat perubahan yang signifikan atau tidak.

Dari hasil penilaian karangan siswa yang dikembangkan berdasarkan curah-gagasan yang dikerjakan secara klasikal dengan berpatokan pada interval nilai yang ditetapkan, terdapat 13 siswa yang mendapat nilai di bawah $70 \%$ dan 17 siswa yang mendapat nilai di atas $70 \%$. Jadi, berdasarkan interval nilai yang ditetapkan, masih terdapat 13 siswa yang mendapat nilai di bawah 70\%. Dari lima aspek yang dinilai dalam menulis karangan, siswa sudah mampu mengarang berdasarkan curah gagasan. Sedangkan kekurangan siswa terletak pada penggunaan EYD dalam mengrang. Artinya, penerapan teknik clustering dalam pembelajaran mengarang pada siswa IV MI Pesanten Datuk Sulaiman Palopo pada siklus I belum berhasil dan akan diperbaiki pada siklus II. Sebaliknya, 17 siswa yang dinyatakan sudah berhasil dengan nilai di atas $70 \%$ dipertahankan, bahkan kalau bisa ditingkatkan pada siklus II.

Subjek dalam observasi ini adalah guru dan siswa. Berdasarkan hasil observasi yang dilakukan selama pembelajaran menulis dilakukan pada siklus I, baik pada pertemuan pertama, kedua, mupun ketiga diperoleh informasi sebagai berikut. Berdasarkan 9 aspek yang dinilai, tidak ada aspek yang mendapat nilai $A$ (sangat baik), ada 3 aspek yang mendapat nilai B (baik), 4 aspek yang mendapat nilai $C$ (kurang baik), dan 2 aspek yang mendapat nilai $D$ (tidak baik). Jadi, semua aspek akan diperbaiki dalam siklus II.

\section{Analisis Temuan Siklus II}

Siklus II merupakan perbaikan terhadap pembelajaran yang dilaksanakan pada siklus I. Jika pada siklus I siswa mengalami hambatan dalam mengarang dengan penerapan teknik clustering, maka dalam siklus II segala hambatan yang ditemukan dalam siklus I tersebut berusaha diperbaiki/diatasi. Dalam siklus II diupayakan siswa mampu membangkitkan daya imajinasi dan semangatnya dalam mengemukakan pikiran dan gagasan. Selain itu, siswa 
diharapkan dapat meningkatkan kreativitasnya dalam melaksanakan hal yang ditugaskan oleh guru.

\section{Tindakan}

Pelaksanaan pembelajaran mengarang berdasarkan pengalaman dengan teknik clustering pada siklus II dilakukan secara kolaborasi antara guru dan peneliti. Guru dan peneliti kembali membuat desain pembelajaran, mendeskripsikan hal-hal yang dipelajari, dan menganalisis kelemahan pembelajaran dalam siklus I, serta merumuskan langkah-langkah antisipasinya. Selanjutnya, guru dan peneliti menyamakan persepsi tentang rencana pembelajaran yang akan diteliti dalam siklus II. Setelah itu, peneliti memberi masukan ulang yang berkaitan dengan sumber belajar, media pembelajaran, dan cara menerapkan teknik clustering.

Dalam kegiatan pendahuluan, guru membuka pelajaran dengan apersepsi dan membangkitkan motivasi belajar siswa untuk mengikuti pelajaran dengan menunjuk salah seorang siswa untuk membaca puisi sebagai hiburan. Selanjutnya, guru mengemukakan tema dan tujuan pembelajaran, yakni mengarang dengan menerapkan teknik clustering. Siswa mulai tampak rileks dalam belajar.

Dalam kegiatan inti, proses pembelajaran berlangsung sebagai berikut.

1) Guru melakukan umpan balik kepada siswa tentang materi pelajaran terdahulu.

2) Guru meminta siswa untuk duduk bersama anggota kelompoknya masing-masing.

3) Guru dan siswa berkolaborasi untuk menentukan tema/topik karangan yang akan ditulis atau dikembangkan berdasarkan pengalaman.

4) Dari hasil kolaborasi guru dan siswa secara kelompok, ditetapkan satu topik tulisan berdasarkan tema yang akan dikembangkan menjadi karangan.

5) Guru menyuruh siswa secara berkelompok membuat curah gagasan berdasarkan hal-hal yang dirasakan dengan menggunakan teknik clustering.

6) Guru memonitor dan membimbing siswa secara kelompok dalam membuat curah gagasan dengan teknik clustering.

7) Selanjutnya, masing-masing siswa membuat karangan berdasarkan pengalaman dengan mengembangkan curah gagasan yang dibuat oleh kelompoknya.

8) Guru menuntun dan mengarahkan siswa untuk mengarang dengan memperhatikan kesesuaian curah gagasan dengan isi karangan, penulisan kata, organisasi karangan, dan penggunaan EYD.

9) Setelah selesai mengarang, guru menyuruh salah seorang siswa dari setiap kelompok untuk membacakan karangannya di depan kelas, kelompok lain memberi tanggapan.

10) Guru menginstruksikan kepada siswa untuk mengumpulkan karangannya berdasarkan kelompoknya masing-masing.

11) Guru menanyakan tanggapan siswa tentang strategi pembelajaran yang telah dilaksanakan pada hari itu

12) Guru kembali menunjuk salah seorang siswa untuk ke depan dan menulis salah satu topik yang ditetapkan. Siswa tersebut menulis curah gagasan yang disebut oleh temantemannya. Selanjutnya, seluruh siswa mengarang berdasarkan pengalaman pribadinya 
tentang liburan sekolah dengan mengembangkan curah gagasan yang telah dibuat secara klasikal.

13) Guru kembali menyuruh siswa untuk membacakan hasil karangannya di depan kelas, siswa lain memberi tanggapan.

14) Setelah itu, hasil karangan siswa dikumpul kepada guru untuk diperiksa dan dinilai.

15) Guru memberikan hadiah kepada siswa yang memiliki karangan terbaik dan memenuhi kategori penilaian, mulai dari peringkat satu sampai dengan peringkat tiga.

16) Guru menanyakan tanggapan siswa yang mendapat hadiah tentang strategi pembelajaran yang telah dilaksanakan pada hari itu.

17) Guru dan siswa menyimpulkan pelajaran.

Kegiatan pembelajaran pada siklus II berlangsung selama dua kali pertemuan, yaitu 4 x 45 menit. Dalam pembelajaran mengarang berdasarkan pengalaman dengan menggunakan teknik clustering, sudah mampu mencurahkan gagasannya dengan asosiasi-asosiasi kata. Siswa tidak lagi merasa malu untuk mencurahkan gagasannya di atas papan tulis ketika guru langsung menunjuk siswa tersebut. Kebingungan siswa pun sudah tidak tampak lagi ketika diminta untuk membuat curah gagasan yang menghubungkan antara lingkaran tengah dengan topik yang dipilih berdasarkan tema pengalaman siswa berupa hal-hal yang dirasakan.

Agar siswa tidak berkeliaran dan mengganggu temannya yang lain, siswa diminta untuk bertanya langsung kepada guru apabila ada hal yang kurang dimengerti. Guru menjadi partner peneliti dalam menerapkan teknik clustering tersebut. Jadi, pembelajaran menulis dengan penerapan teknik clustering berlangsung secara maksimal.

\section{Pengamatan}

Pembelajaran pada siklus II dilaksanakan dalam dua kali pertemuan dan berlangsung selama 4 x 45 menit. Dalam pembelajaran mengarang berdasarkan pengalaman pribadi dengan menggunakan teknik clustering siswa kelas IV MI Pesanten Datuk Sulaiman Palopo sudah mampu mencurahkan gagasannya dengan asosiasi-asosiasi kata. Siswa tidak lagi merasa malu untuk mencurahkan gagasannya di atas papan tulis ketika guru langsung menunjuk siswa tersebut. Kebingungan siswa pun sudah tidak tampak lagi ketika diminta untuk membuat curah gagasan yang menghubungkan antara lingkaran tengah dengan topik yang dipilih berdasarkan tema pengalaman siswa berupa hal-hal yang dirasakan dan ditemukan pada saat liburan sekolah.

Agar siswa tidak berkeliaran dan mengganggu temannya yang lain, siswa diminta untuk bertanya langsung kepada guru apabila ada hal yang kurang dimengerti. Guru menjadi partner peneliti dalam menerapkan teknik clustering tersebut. Jadi, pembelajaran menulis dengan penerapan teknik clustering yang berlangsung secara maksimal.

\section{Refleksi}

Berdasarkan refleksi pada siklus II ini disimpulkan bahwa kegiatan pembelajaran mengarang berlangsung secara optimal karena guru telah mampu memberikan pemahaman kepada siswa tentang tata cara pelaksanaan pembelajaran menulis dengan teknik clustering. Teknik clustering telah diterapkan dengan baik karena guru dengan maksimal mengarahkan siswa secara bertahap dalam mengarang sehingga siswa memberi respons yang positif. 
Refleksi pada siklus II menunjukkan bahwa siswa mampu membangkitkan semangat, minat, dan kreativitasnya dalam menerima pelajaran dan menciptakan sebuah karangan. Dalam pembelajaran, siswa tampak merasa senang dan bersemangat sehingga dengan sendirinya mereka aktif dan kreatif meningkatkan potensi yang ada dalam dirinya. Tahap ini pula dapat mengaktifkan dan mengkreatifkan siswa yang masih kurang kreatif dalam mengarang berdasarkan pengalaman pribadi mereka tentang liburan sekolah.

Dalam siklus II ini, tidak tampak siswa yang tidak maksimal dalam mengarang berdasarkan pengalaman pribadi. Keberhasilan siklus ini merupakan hasil perbaikan terhadap temuan yang diperoleh dari siklus I. Pembelajaran tidak lagi dilaksanakan pada jam pelajaran terakhir. Kondisi dan suasana kelas tidak lagi ribut sehingga kegiatan pembelajaran menjadi optimal. Faktor lain yang menyebabkan pembelajaran maksimal, yaitu: guru secara aktif memantau kegiatan siswa.

Pelaksanaan pembelajaran menulis dengan teknik clustering membuat siswa merasa senang, bersemangat, tetapi rileks. Dari sejumlah karangan yang dikumpulkan oleh guru, dapat disimpulkan bahwa seluruh siswa mampu membuat karangan sesuai dengan target. Karangan siswa telah memenuhi aspek penilaian seperti curah gagasan yang dibuat sesuai dengan isi karangan, jumlah kata, pemilihan kata, organisasi karangan, dan penggunaan PUEBI telah memadai. Jadi, karangan yang dibuat oleh siswa telah memenuhi syarat penilaian. Rasa percaya diri siswa dalam menulis menjadi lebih meningkat. Hal ini terbukti bahwa siswa bersemangat membaca karangannya tanpa merasa malu dan mereka senang dengan hasil pekerjaannya. Terlebih lagi ketika guru memberikan hadiah sebagai penguatan kepada siswa yang karangannya terbaik I, II, dan III.

\section{Temuan Analisis Siklus II}

Untuk mengukur keberhasilan pembelajaran dalam siklus II dilakukan evaluasi. Evaluasi (penilaian) dalam pembelajaran menulis pada siklus II ini dilakukan dalam dua bentuk, yaitu penilaian proses dan penilaian hasil belajar. Penilaian proses dilakukan dengan mengamati kegiatan siswa pada saat kegiatan pembelajaran mengarang berlangsung. Hal yang dinilai adalah kegiatan siswa yang meliputi: hal yang dilakukan, kesulitan yang dihadapi, cara siswa mengatasi kesulitannya, dan hal yang dilakukan untuk mengefektifkan pembelajaran siswa.

Temuan penelitian yang diperoleh dari hasil analisis siklus II diuraikan sebagai berikut.

1) Guru memotivasi siswa dengan menyuruh salah satu siswa membaca puisi.

2) Kegiatan pembelajaran mengarang berlangsung secara optimal karena guru telah mampu memberikan pemahaman kepada siswa tentang tata cara pelaksanaan pembelajaran menulis dengan teknik clustering.

3) Teknik clustering telah diterapkan dengan baik karena guru dengan maksimal mengarahkan siswa secara bertahap dalam mengarang sehingga siswa memberi respons yang positif.

4) Siswa mampu membangkitkan semangat, minat, dan kreativitasnya dalam menerima pelajaran dan menciptakan sebuah karangan.

5) Dalam pembelajaran, siswa tampak merasa senang dan bersemangat sehingga dengan sendirinya mereka aktif dan kreatif meningkatkan potensi yang ada dalam dirinya.

6) Siswa tidak lagi mengalami kesulitan mengembangkan curah gagasan yang dibuat.

7) Penilaian guru terhadap hasil karangan siswa mendapat respons yang baik, karena guru memberi penguatan berupa pemberian hadiah bagi karangan yang terbaik. 
Berdasarkan hasil observasi yang dilaksanakan selama pembelajaran menulis dilakukan pada siklus II, baik pada pertama maupun kedua diperoleh informasi, yaitu kesembilan aspek yang dinilai telah mencapai nilai $A$ (sangat baik) sebagai nilai maksimal berkat refleksi yang dilakukan pada siklus I.

\section{Kesimpulan}

Hasil penelitian menunjukkan bahwa penerapan teknik clustering dapat meningkatkan pembelajaran menulis karangan deskripsi siswa kelas IV MI Pesanten Datuk Sulaiman Palopo. Peningkatan yang dimaksud, yaitu peningkatan proses dan hasil belajar menulis karangan deskripsi siswa. Peningkatan tersebut tampak pada proses pembelajaran siklus I dan siklus II.

Berdasarkan hasil penelitian ini, disarankan, yaitu: 1) Guru kelas IV MI Pesanten Datuk Sulaiman Palopo menerapkan teknik clustering yang sebagai salah satu metode pengajaran yang digunakan untuk mengarahkan siswa dalam mengembangkan kemampuan menulis karangan deskripsi; 2) Siswa hendaknya lebih meningkatkan kompetensi menulisnya dengan menerapkan teknik clustering karena teknik ini membantu menciptakan ide dan menciptakan kesenangan dalam belajar.

Peneliti selanjutnya, hendaknya mengkaji teknik clustering dengan materi yang berbeda sehingga menambah pengetahuan tentang peran teknik clustering dalam pembelajaran bahasa Indonesia.

\section{Referensi}

Alwi, H., et al. (2001). Kamus Besar Bahasa Indonesia Edisi III. Jakarta: Balai Pustaka.

Aminuddin. (2003). Kemampuan Siswa Kelas V SDN 68 Cangadi Menulis Karangan Deskripsi dengan Bantuan Gambar. Skripsi. Makassar: FBS UNM.

Arikunto, S. (1998). Prosedur Pen-elitian. Jakarta: Rineka Cipta.

Depdiknas. (2003). Kurikulum 2004 Standar Kompetensi Mata Pelajaran Bahasa Indonesia. Jakarta: Depdiknas.

Deporter, B. \& Hernacki, M. (2005). Quantum Learning: Membiasakan Belajar Nyaman dan Menyenangkan. Bandung: Kaifa.

Enre, F. A. (1994). Dasar-dasar keterampilan Menulis. Ujung Pandang: Badan Penerbit IKIP Ujung Pandang.

Halim, A. (2004). Teknik Pengajaran Menulis. Jakarta: Djambatan.

Hernowo. (2003). Quantum Writing: Cara Cepat dan Bermanfaat untuk Merangsang Munculnya Potensi Menulis. Bandung: MLC.

Keraf, G. (2004). Argumentasi dan Deskripsi. Jakarta: PT Gramedia Pustaka Utama.

Milles, M. \& Huberman, M. (1992). Analisis Data Kualitatif. Diterjemahkan oleh Tjetjep Rohendi Rohidi. Jakarta: Universitas Indonesia.

Nurgiyantoro, B. (1995). Penilaian dan Pengajaran Bahasa dan Sastra. Yogyakarta: BPFE.

Nurdjan, S., Firman, \& Mirnawati. (2016). Bahasa Indonesia Untuk Perguruan Tinggi. Makassar: Penerbit Aksara Timur.

Parera, J. S. \& Tasai, S. A. (1996). Pintar Berbahasa. Jakarta: Balai Pustaka.

Priyono. (2004). KBK: Solusi atau Bencana Pendidikan.

Tolla, A. (1991). Retorika Menulis Siswa Kelas II SMAN di Kotamadya Ujung Pandang. Laporan Penelitian. Ujung Pandang: IKIP Ujung Pandang.

Widyamartaya. (1978). Kreatif Mengarang. Yogyakarta: Kanisius. 